\title{
Industriele organisatie en chaostheorie : de analyse van turbulente markten
}

Citation for published version (APA):

van Witteloostuijn, A., \& Boone, C. A. J. J. (1997). Industriele organisatie en chaostheorie : de analyse van turbulente markten. NIBOR, Netherlands Institute of Business Organization and Strategy Research. NIBOR Research Memorandum No. 004 https://doi.org/10.26481/umanib.1997004

Document status and date:

Published: 01/01/1997

DOI:

10.26481/umanib.1997004

Document Version:

Publisher's PDF, also known as Version of record

\section{Please check the document version of this publication:}

- A submitted manuscript is the version of the article upon submission and before peer-review. There can be important differences between the submitted version and the official published version of record.

People interested in the research are advised to contact the author for the final version of the publication, or visit the DOI to the publisher's website.

- The final author version and the galley proof are versions of the publication after peer review.

- The final published version features the final layout of the paper including the volume, issue and page numbers.

Link to publication

\footnotetext{
General rights rights.

- You may freely distribute the URL identifying the publication in the public portal. please follow below link for the End User Agreement:

www.umlib.nl/taverne-license

Take down policy

If you believe that this document breaches copyright please contact us at:

repository@maastrichtuniversity.nl

providing details and we will investigate your claim.
}

Copyright and moral rights for the publications made accessible in the public portal are retained by the authors and/or other copyright owners and it is a condition of accessing publications that users recognise and abide by the legal requirements associated with these

- Users may download and print one copy of any publication from the public portal for the purpose of private study or research.

- You may not further distribute the material or use it for any profit-making activity or commercial gain

If the publication is distributed under the terms of Article $25 \mathrm{fa}$ of the Dutch Copyright Act, indicated by the "Taverne" license above, 
Industriële organisatie en chaostheorie: De analyse van turbulente markten

A. van Witteloostuijn \& C. Boone

NIBOR/RM/97/04

http://www.unimaas.nl/ document/fdewb.htm

J.E.Lit. code: L13

$n i b \circ r$

Netherlands Institute of

Business Organization

and Strategy Research

University of Maastricht

Faculty of Economics and Business Administration

P.O. Box 616

6200 MD Maastricht

The Netherlands

Phone: ++31 43 - 3883805 


\title{
Fax : ++3143-3258495 \\ INDUSTRIËLE ORGANISATIE EN CHAOSTHEORIE
}

De analyse van turbulente markten

\author{
door \\ Arjen van WITTELOOSTUIJN \\ en \\ Christophe BOONE*
}

\author{
Universiteit Maastricht \\ Faculteit der Economische Wetenschappen en Bedrijfskunde \\ Vakgroep Managementwetenschappen \\ Sectie Organisatie en NIBOR \\ Postbus 616 \\ 6200 MD Maastricht
}

"Beide auteurs zijn hoogleraar bedrijfseconomie, in het bijzonder organisatie. 


\section{SAMENVATTING}

Het voorwerp van onderzoek van de wiskundige theorie van niet-lineaire dynamica - bekend geworden onder de naam chaostheorie - is het modelleren en begrijpen van turbulentie. De vaststelling dat het economische leven alsmaar dynamischer en onzekerder wordt, heeft vele economen doen grijpen naar chaostheoretische concepten en inzichten. Dit heeft eveneens een beperkt aantal modellen van marktwerking (industriële organisatie) opgeleverd. In deze bijdrage worden deze toepassingen binnen de industriële organisatie besproken en geëvalueerd. Alle toepassingen blijken neer te komen op het ad hoc introduceren van heuvelvormige reactiefuncties in een speltheoretisch model van Cournot-duopolieconcurrentie. Nadat de werking van een dergelijk model is geïllustreerd, wordt ingegaan op de plausibiliteit van het bestaan van heuvelvormige reactiefuncties in het bijzonder en "chaotische" markten in het algemeen. 


\section{INLEIDING}

Het is bijna een traditie geworden in de (bedrijfs)economische wetenschappen: ieder artikel wordt ingeleid met de mededeling dat het economische leven alsmaar onzekerder en turbulenter wordt ten gevolge van de "globalisering" van de economie, de introductie van nieuwe technologieën, kortere productlevenscycli, etc. Deze evolutie heeft het leven van (bedrijfs)economen niet eenvoudiger gemaakt omdat hun overwegend statische theorieën niet toelaten nauwkeurige voorspellingen te maken in een wereld waar turbulentie eerder de regel dan de uitzondering schijnt te zijn. Het voorwerp van onderzoek van de "economische" chaostheorie is nu precies het modelleren en begrijpen van turbulentie. Het hoeft dan ook niet te verbazen dat toepassingen van de chaostheorie in de afgelopen tien jaar een steeds belangrijkere rol zijn gaan spelen in het onderzoek naar dynamische processen in organisaties, markten, bedrijfstakken en economieën (Benhabib en Day, 1980 \& 1982; Burgelman, 1983; Freedman, 1992; Goldstein, 1988; Nonaka, 1988; Romme \& van Witteloostuijn, 1997; van Witteloostuijn en van Lier, 1990; Wijnberg en Janszen, 1993).

Romme en van Witteloostuijn (1997) onderscheiden twee stromingen in de toepassingen van de chaostheorie in de economische wetenschappen: de mathematische en de conceptuele benadering. De mathematische benadering is een positieve theorie in de zin dat chaostheoretici de werkelijkheid trachten te beschrijven en te analyseren zoals die zich aan ons voordoet. De conceptuele benadering, die vooral populair is in de bedrijfskunde, is een normatief perspectief dat zich richt op de organisatorische consequenties die volgen uit chaostheoretische inzichten. Aangezien de toepassingen van de chaostheorie in de industriële organisatie, het onderwerp van deze bijdrage, zuiver mathematisch van aard zijn, laten we in dit artikel de conceptuele benadering buiten beschouwing.

Een belangrijk inzicht van de mathematische chaostheorie is dat schijnbaar stochastische fenomen het gevolg kunnen zijn van niet-lineaire deterministische dynamica. Meer bepaald kunnen in een systeem waarin naast dempende (negatieve) ook versterkende (positieve) terugkoppelingen optreden, chaotische patronen voorkomen. Met andere woorden: het zijn niet-lineariteiten die systemen binnen bepaalde grenzen chaotisch kunnen maken. Nietlineaire dynamiek is een noodzakelijke, maar overigens geen voldoende voorwaarde. De eigenschappen van niet-lineaire systemen met een chaotisch interval kunnen worden geïllustreerd aan de hand van een concrete wiskundige formulering. Het vertrekpunt is een eerste-ordedifferentievergelijking (May, 1976):

$x_{t+1}=f\left(x_{t}\right)$.

Deze vergelijking kan met chaotische trajecten van variabele $\mathrm{x}$ (bij voorbeeld productprijzen of beurskoersen) zijn geassocieerd indien de functie $f$ een niet-lineaire vorm heeft met voldoende steile helling die een tekenwisseling kent in de eerste afgeleide. Overigens kunnen ook systemen van of met dergelijke niet-lineaire differentievergelijkingen chaotische trajecten kennen. Daarnaast is het bestaan van chaos niet beperkt tot de klasse van eersteordedifferentievergelijkingen. Ook differentiaalvergelijkingen kunnen bij voorbeeld geassocieerd zijn met chaotische uitkomsten. 
Een definitie van mathematische chaos is niet eenvoudig te geven (Baumol en Benhabib, 1989). Zonder in te gaan op de precieze mathematische eigenschappen van chaotische systemen (Kelsey, 1988), kan een drietal kenmerkende eigenschappen worden aangegeven: (1) chaotische regimes, in de vorm van niet-repetitieve patronen van variabele $x$ over een specifieke tijdperiode, treden op voor specifieke intervallen van parameterwaarden; (2) de uitkomsten van het dynamische proces (in de vorm van een tijdreeks van variabele $x$ ) zijn uiterst gevoelig voor de begincondities; en (3) het patroon van de variabele $x$ vertoont plotselinge kwalitatieve breuken in de zin dat perioden van ogenschijnlijke regelmaat worden onderbroken door tijdintervallen zonder regelmaat.

Het is duidelijk dat de chaostheorie impliceert dat veranderingsprocessen in economische en sociale systemen fundamenteel onvoorspelbaar zijn. Indien economische systemen daadwerkelijk gekenmerkt worden door deterministische chaos, zijn voorspellers gedoemd tot werkloosheid. Stochastische fenomen daarentegen zijn in principe, indien de onderzoeker over valide dynamische theorieën beschikt, voorspelbaar op toevallige schommelingen na. Binnen de econometrie is inmiddels een moeilijke speurtocht begonnen naar toetsmethodologieën waarmee deterministische chaos van stochastische fenomenen kan onderscheiden worden (Brock, 1986).

De "economische" chaostheorie kent veruit de meeste toepassingen in het domein van de macro-economie (Benhabib en Day, 1980 \& 1982). Deze macromodellen zijn vooral gericht op de verklaring van chaotische patronen in macro-economische tijdreeksen. Een tweede reeks van toepassingen betreft niet-lineaire micromodellen van het keuzegedrag van economische agenten (consumenten en ondernemingen). Deze tweede klasse van modellen bevat eveneens de zeldzame toepassingen in het domein van de industriële organisatie. In de moderne industriële organisatie worden concurrentieprocessen systematisch geanalyseerd met behulp van mathematische speltheoretische modellen (Tirole, 1988). De huidige bijdrage van de chaostheorie beperkt zich tot de introductie van niet-lineaire reactiefuncties in zulke modellen, met name Cournot-duopoliespellen. Het doel van deze exercities is uitermate bescheiden. Meer bepaald is het de wens om te illustreren dat ten gevolge van niet-lineaire reactiefuncties actie-reactiepatronen kunnen ontstaan die chaotische tijdreeksen van productievolumina genereren. Dat wil zeggen: beide producenten krimpen en groeien zonder dat daar ogenschijnlijk enige systematiek in kan herkend worden. Het doel van dit artikel is zowel de huidige als potentiële bijdragen van de chaostheorie aan de industriële organisatie kritisch te evalueren.

In de tweede paragraaf gaan we dieper in op niet-lineaire modellen van Cournotconcurrentie. Het bestaan van chaotische regimes wordt aangetoond aan de hand van een model van van Witteloostuijn en van Lier (1990; verder met W\&L aangegeven). De implicaties van het model worden geïllustreerd met behulp van simulatie-experimenten in de derde paragraaf. In de vierde paragraaf wordt beargumenteerd dat de bijdrage van deze klasse van micromodellen tot het begrijpen van de werking van concurrentieprocessen zeer beperkt is. Wij menen dat vele onderzoekers slechts op zoek zijn naar een quasi-toepassing van de nieuwste mathematische technieken. In dit verband kan bij voorbeeld vastgesteld worden dat in de huidige literatuur geen of nauwelijks aandacht wordt besteed aan de validiteit van de 
veronderstellingen die nodig zijn om niet-lineaire reactiefuncties te genereren. In de vijfde paragraaf verlaten we de "chaotische" wereld van niet-lineaire Cournot-concurrentie. We argumenteren dat onderzoekers meer aandacht zouden moeten besteden aan het beantwoorden van een aantal fundamentele basisvragen: in welke mate, waarom en wanneer vertonen productmarkten ${ }^{1}$ chaotische patronen, en zijn sommige productmarkten gevoeliger voor chaos dan andere? In dit verband menen we dat het functioneren van vele productmarkten niet kan begrepen worden met behulp van chaostheoretische inzichten alleen. De reden hiervoor is dat deze theorie voorbij gaat aan twee gerelateerde kenmerken van het functioneren van economische agenten (in dit artikel ondernemingen) die krachten richting chaos dempen: (1) het gedrag van economische agenten is onderhevig aan zowel interne als externe restricties die (tot doel hebben) voorspelbaar gedrag (te) genereren; en (2) economische agenten trachten de omgeving te beheersen aangezien zij geen baat hebben bij chaos. Onvoorspelbaarheid wordt bestreden met strategieën die onzekerheidreductie bewerkstelligen.

\section{NIET-LINEAIRE MODELLEN VAN COURNOT-CONCURRENTIE}

In het standaard Cournot-duopoliemodel (1838) wordt gesteld dat een onderneming i zijn productievolume $^{2}(\dot{q})$ zodanig kiest dat haar winst (п) gemaximaliseerd wordt, rekening houdend met de hoeveelheid aangeboden door haar rivaal $j\left(q^{j}\right)$ :

$\operatorname{Max} \pi^{i}=p\left(q^{i}+q^{j}\right) q^{i}-c^{i}\left(q^{i}\right)$

$q^{i}$

waarbij $p$ de inverse vraagfunctie en bijgevolg de prijs weergeeft, en $c$ de gemiddelde totale productiekost is. Maximalisatie van (1) geeft de volgende eerste-ordeconditie:

$p\left(q^{i}+q^{j}\right)+q^{i} d p / d\left(q^{i}+q^{j}\right)\left(1+d q^{j} / d q^{i}\right)-d c^{i} / d q^{i}=0$

Uit conditie (2) kan de reactiefunctie van onderneming i afgeleid worden:

$q^{i}=r^{i}\left(q^{j}\right)$

waarvoor geldt dat $\mathrm{i}, \mathrm{j}=1,2$ en $\mathrm{i} \neq \mathrm{j}$ met de Nash-veronderstelling dat de onderneming verwacht dat haar rivaal passief reageert op haar volumestrategie op grond van myopische verwachtingen. In standaard Cournot-duopoliemodellen (Tirole, 1988) wordt verondersteld dat de reactiefuncties (3) lineair of onvoldoende niet-lineair zijn (dat wil zeggen: zonder top). ${ }^{3}$ Deze veronderstelling garandeert dat geen chaotische patronen kunnen optreden.

De schaarse toepassingen van chaostheorie in de industriële organisatie versoepelen precies deze veronderstelling met betrekking tot de vorm van de reactiefuncties. Meer bepaald tonen Rand (1978), Dana en Montrucchio (1986) en W\&L (1990) aan dat de productievolumina van beide rivalen chaotische patronen kunnen vertonen wanneer de reactiefunctie van ten minste één van de rivalen voldoende niet-lineair is (dat wil zeggen: heuvelvormig). In dit artikel illustreren we 
de werking van chaos aan de hand van het model van W\&L (1990). De andere modellen zijn minder realistisch omdat daarin (impliciet) wordt verondersteld dat onderneming i niets produceert wanneer onderneming $j$ hetzelfde doet $\left[\mathrm{r}^{i}(0)=q^{i}=0\right.$ : de reactiefunctie gaat door de oorsprong]. Het model van W\&L (1990) introduceert daarentegen een positieve monopolieproductie $\left[q_{M}^{i}=r^{i}(0)\right.$ $>0$, waarbij $q_{M}^{i}$ de monopolieproductie van onderneming i voorstelt]. De volgende figuur illustreert een dergelijke reactiefunctie.

\section{FIGUUR 1 HIER INVOEGEN}

Het is duidelijk dat een heuvelvormige reactiefunctie zoals weergegeven in figuur 1 een asymmetrisch reactiepatroon impliceert. Voor $q^{j}<q_{T}^{j} z i j n$ de productievolumina van onderneming i en j positief gecorreleerd. Voor $q^{j}>q_{T}^{j}$ geldt het omgekeerde. Dus: voor kleine waarden van $\dot{q}$ is onderneming $\mathrm{i}$ een volger of imitator, en reageert de onderneming agressief op productieexpansie van haar rivaal. Voor grote waarden van $q^{j}$ accommodeert onderneming $i$ haar productievolume in functie van de acties van onderneming j. Met andere woorden: in dit geval wordt de productiebeslissing van onderneming i bepaald door het niveau van de residuele vraag. Het asymmetrisch reactiepatroon volgt dus uit de omkering van het teken van de eerste-ordeafgeleide van de reactiefunctie. Een onderneming met een asymmetrisch reactiepatroon kan een dualist genoemd worden: het antwoord op de acties van een rivaal kan agressief of accommoderend zijn, afhankelijk van de omvang van het productievolume van de concurrent.

Een belangrijke vraag dringt zich op: kan een economisch plausibele reden verschaft worden voor zulk een asymmetrisch reactiepatroon? Een economische interpretatie van heuvelvormige reactiefuncties met positieve monopolieproductie wordt geleverd door Bulow, Geanaklopos en Klemperer (1985). Startend vanuit de situatie waarbij één onderneming het monopolievolume produceert, is de intuïtieve interpretatie als volgt. De monopolist is in eerste instantie bereid zijn productie te verhogen wanneer een rivaal toetreedt tot de markt (hetgeen tegenstrijdig is met de negatieve helling van standaard Cournot-reactiefuncties). Deze gedachtengang is gebaseerd op de theorie over toetredingsbelemmerende strategieën. Bij voorbeeld: ondernemingen met overcapaciteit kunnen een expansiestrategie na toetreding gebruiken om verdere potentiële toetreders af te schrikken (Spence, 1977 \& 1979; Ware, 1985). Wanneer de omvang van de rivaal echter groot wordt, is deze expansiestrategie niet meer winstgevend. Met andere woorden: in tegenstelling tot het nut van een agressieve strategie, stijgt het voordeel van accommodatie met de omvang van de concurrent (hetgeen de standaard negatieve helling van de Cournotreactiecurve impliceert).

$\mathrm{Li}$ en York (1975) leveren een theorema dat toelaat het bestaan van chaotische regimes in eerste-ordedifferentievergelijkingen te bewijzen. W\&L (1990) tonen vervolgens met behulp van dit theorema aan dat chaotische patronen van productievolumina kunnen gegenereerd worden wanneer ten minste één van beide concurrenten een dualist is (dat wil zeggen: een voldoende niet-lineaire - heuvelvormige - reactiefunctie heeft). W\&L (1990) bewijzen, met andere woorden, dat voor bepaalde parameterwaarden producenten krimpen en groeien zonder dat daar ogenschijnlijk enige systematiek in kan herkend worden. ${ }^{4}$ 


\section{SIMULATIERESULTATEN}

In hetgeen volgt illustreren we de werking van chaos aan de hand van een simulatie van het concurrentieproces in de vorm van een reeks van strategische acties en reacties (zie hiervoor $W \& L, 1990)$. De simulatie heeft betrekking op 120 perioden $(t=1, \ldots, 120)$. Dus: beide rivalen nemen 60 productiebeslissingen. Rivaal $i$ beslist in oneven perioden $(t=1,3,5, \ldots, 119)$, en concurrent $\mathrm{j}$ reageert in even perioden $(t=2,4,6, \ldots, 120)$. Het experiment is een simulatie van een dualist (onderneming i) die tegen een agressieve rivaal concurreert (dat wil zeggen: imitator $j)$. De reactiefunctie van onderneming $i$ is als volgt gespecificeerd:

$q^{i}=r^{i}\left(q^{j}\right)=1-\alpha\left(q^{j}-1+1 / \sqrt{ } \alpha\right)^{2}$

Onderneming j heeft een reactiefunctie van de vorm weergegeven in vergelijking (3) met een positieve helling. Merk op dat de resultaten van de simulaties gedreven worden door de volgende initialisaties: (1) de waarde van de parameter $\alpha$ bepaalt de steilheid van de niet-lineaire reactiecurve van onderneming i; en (2) variaties met betrekking tot de eerste strategische actie van onderneming $\mathrm{i}$ ( $\mathrm{q}_{1}^{i}$ of, met andere woorden, de monopolieproductie) bepalen de initiële concurrentie-omgeving. Aangezien de resultaten gelijksoortig zijn voor beide rivalen, worden enkel de productiebeslissingen van onderneming i weergegeven (voor oneven perioden). In tabel 1 staan de initiële waarden van de simulatie-experimenten samengevat.

\section{TABEL 1 HIER INVOEGEN}

Met de simulatie-experimenten worden drie eigenschappen van niet-lineaire dynamica geïllustreerd: (1) chaotische regimes bestaan slechts voor specifieke parameterwaarden; (2) de resultaten zijn sterk afhankelijk van initiële condities; en (3) in de patronen treden plotse kwalitatieve breuken op.

Alvorens de simulatieresultaten te presenteren kan nog een bemerking worden gemaakt ter zake het dynamische karakter van de niet-lineaire modellen van Cournot-concurrentie. Immers: hoewel alle bestaande toepassingen van chaostheoretische inzichten binnen het domein van de industriële organisatie zich beperken tot de introductie van niet-lineariteiten in de winstfuncties van ondernemingen die opereren in een basale Cournot-omgeving, kan niet worden ontkend dat deze context slechts in beperkte mate dynamisch kan worden genoemd. De dynamische signatuur van deze modeluitwerkingen schuilt alleen in het herhaalde karakter ervan. Dat wil zeggen: de ondernemingen spelen hetzelfde Cournot-spel in een opeenvolging van $\mathrm{n}$ perioden. Een manco van deze uitwerking is dat de koppeling tussen de gebeurtenissen in opeenvolgende perioden sterk mechanisch is ten gevolge van de veronderstelling dat de ondernemingen statische - of: myopische - verwachtingen hanteren. Deze, overigens niet ongebruikelijke, veronderstelling houdt in dat wordt aangenomen dat onderneming i bij de vaststelling van het eigen productieniveau in periode $t$ verwacht dat concurrent $\mathrm{j}$ zijn productiehoeveelheid uit periode $\mathrm{t}-1$ zal handhaven in periode t. Deze extreme variant van adaptieve verwachtingen zou in toekomstig onderzoek moeten worden losgelaten, zodat het dynamische karakter van de modellen verder wordt versterkt. Vooreerst is het echter nuttig een begin te maken met de 
analyse van chaotische markten door te vertrekken vanuit de eenvoudige variant met myopische verwachtingen.

\section{Chaotische patronen}

Een eerste implicatie van niet-lineaire dynamica is uiteraard de mogelijkheid dat chaotische trajecten opduiken. Als ten minste één van beide rivalen in een Cournot-duopoliespel beslissingen neemt op basis van een voldoend niet-lineaire reactiefunctie, dan lijkt het verloop van de productiebeslissingen van beide concurrenten in de tijd op een "random walk". Dit wordt geïllustreerd in figuur 2.

\section{FIGUUR 2 HIER INVOEGEN}

In periode $t=1$ produceert onderneming i de monopolieproductie. De daaropvolgende reacties van onderneming $i$ (en j) vertonen een chaotisch traject. De tijdreeks van productievolumina vertoont geen enkel systematisch (periodisch) patroon: de geschiedenis herhaalt zich niet. Bij voorbeeld: het patroon van productievolumina van periode $t=105$ tot $t=109$ verschilt kwalitatief van alle trajecten in verleden en toekomst.

\section{Gevoelige afhankelijkheid van initiële condities}

De tweede eigenschap kan worden geïllustreerd door kleine wijzigingen aan te brengen in de initiële condities. In simulatie II is de monopoliehoeveelheid minuscuul kleiner dan in de eerste simulatie (een reductie van 0,01). In figuur 3 wordt duidelijk weergegeven dat het traject van de volumina van onderneming i hierdoor drastisch wijzigt. Met andere woorden: "history matters".

\section{FIGUUR 3 EN 4 HIER INVOEGEN}

Bij vergelijking van figuur 2 en 3 valt bij voorbeeld op dat geen enkele gelijkenis bestaat tussen de productietrajecten gegenereerd via simulatie I en II voor de perioden $t=57$ tot $t=65$ en $t=$ 79 tot $t=83$. In het derde experiment (III: zie figuur 4) wordt het monopolievolume op dezelfde waarde gehouden als in experiment I, maar de waarde van parameter $\alpha$ wordt licht gereduceerd (van 3,35 naar 3,34). Opnieuw stellen we vast (vergelijk figuur 2 en 4) dat zulk een kleine wijziging het productietraject van onderneming i drastisch wijzigt.

\section{Kwalitatieve breuken}

Een eigenaardige eigenschap van niet-lineaire dynamica is dat chaotische trajecten plotse breuken kunnen vertonen in het kwalitatieve patroon. In het vierde experiment (IV), waarin de monopolieproductie verhoogd werd van 0,30 naar 0,998 met een waarde van $\alpha$ gelijk aan het niveau in experiment I en II, duiken plotseling twee perioden op waarin de productiebeslissingen van onderneming i een stabiel patroon vertonen (zie figuur 5).

\section{FIGUUR 5 HIER INVOEGEN}


Voor twee korte tijdperioden in dit voorbeeld schijnt de geschiedenis zich te herhalen. Meer bepaald is het productievolume voor de perioden $t=11$ tot $t=19$ en $t=105$ tot $t=113$ quasiconstant, hetgeen convergentie naar een uniek evenwicht suggereert. Na periode $t=21$ respectievelijk $t=115$ vervalt het patroon echter opnieuw in chaos.

\section{EVALUATIE VAN NIET-LINEAIRE MODELLEN VAN COURNOT-CONCURRENTIE}

Uit het voorgaande wordt duidelijk dat het al dan niet voorkomen van chaotische regimes staat of valt met de veronderstelling van asymmetrische reactiepatronen. Een zeer belangrijke vraag is dan ook of de veronderstellingen die ten grondslag liggen aan zulke reactiepatronen, plausibel zijn. Hoewel in de vorige paragraaf op basis van a priori veronderstellingen (dat wil zeggen: intuïtie) een economische uitleg werd verschaft voor het bestaan van heuvelvormige reactiefuncties (zie ook W\&L, 1990), blijken de formele veronderstellingen die nodig zijn om zulke reactiefuncties te genereren niet overdreven plausibel te zijn (Rauscher, 1992). Als wordt uitgegaan van de gebruikelijke veronderstelling dat ondernemingen winsten maximaliseren, dan (i) kunnen heuvelvormige reactiefuncties in een Cournot-model per definitie slechts het gevolg zijn van niet-lineariteiten in de winstfuncties, terwijl (ii) in Bertrand-modellen - met de prijs als strategische variabele - dergelijke heuvelvormige reactiefuncties zijn uitgesloten (van Witteloostuijn, 1988). Uit vergelijking (1) volgt onmiddellijk dat dit eerste theoretisch enkel kan geïnduceerd worden door (weinig plausibele) niet-lineaire vraag- en/of kostenfuncties. Het hoeft dan ook niet te verbazen dat in vorig onderzoek het dilemma van de specificatie van zulke vraag- en kostenfuncties vermeden werd door heuvelvormige reactiefuncties ad hoc te postuleren op basis van a priori argumenten (of intuïtie). W\&L (1990: 179) besluiten dat de huidige stand van zaken "[r]aises the question whether there is a (large) class of economically plausible demand and/or cost functions which predicts such asymmetries". Wat dit betreft zijn wij net zo pessimistisch als Kelsey (1988: 19), die stelt dat "[t]he shapes of the reaction functions ... are very extreme indeed. It does not look like they could be generated by plausible demand and cost functions".

Een andere, tot op heden niet geëxploreerde, weg om heuvelvormige reactiefuncties te genereren is door afstand te nemen van het postulaat dat ondernemingen enkel winst maximaliseren. Met andere woorden: daarmee zou rechtstreeks worden ingegrepen in de nutsfuncties van ondernemingen [zie vergelijking (1)]. Bij wijze van illustratie werken we een voorbeeld uit waarbij concurrentie tussen ondernemingen beschouwd wordt als een statusspel. Statusspellen werden tot dusverre met name gebruikt om het gedrag van consumenten te beschrijven. In een statusspel wordt ervan uitgegaan dat een consument niet enkel nut haalt uit de eenvoudige consumptie van het goed zelf, maar ook uit de status die aan de consumptie van dat goed verbonden is. Met andere woorden: bezit of consumptie van een goed bepaalt iemands positie in de samenleving. De gevolgen die het streven naar status met zich mee kan brengen, worden als volgt beschreven door Rauscher (1992: 287): "[s]ince each person wants to rank as high as possible in society, he or she consumes the more of these positional goods the more the other people are consuming. This may result in a rat race or treadmill in which inefficiently large quantities of positional goods are consumed". In zulke statusspellen zijn heuvelvormige reactiefuncties van consumenten relatief standaard, en eenvoudig te interpreteren (zie Rauscher, 1992). In hetgeen volgt passen we het model van Rauscher toe op twee concurrerende 
ondernemingen. Onze eerste gedachtenexperimenten kennen uiteraard een hypothetisch -zij het hopelijk plausibel - karakter. Verder formeel-wiskundig onderzoek zal nodig zijn om onze vermoedens analytisch te onderbouwen. In dit artikel beperken wij ons echter tot de schets van de modelstructuur en de eraan gekoppelde gedachtengang.

Onderneming i maximaliseert een strict quasi-concave nutsfunctie $[u(.,)$.$] bestaande uit twee$ componenten: winst ( $\pi)$ en marktstatus (s). ${ }^{5}$ De marktstatus van onderneming $i$ hangt af van de eigen omvang (q) en van de omvang van de rivaal $(\mathrm{Q})$. De marktstatusfunctie heeft de volgende eigenschappen: $\mathrm{s}_{\mathrm{q}}>0, \mathrm{~s}_{\mathrm{Q}}<0, \mathrm{~s}_{\mathrm{qq}}<0$ en $\mathrm{s}_{\mathrm{qQ}}<0$ (eenvoudigheidshalve is de notitie aangepast: $\mathrm{s}_{\mathrm{q}}$ is bij voorbeeld de eerste afgeleide van $\mathrm{s}$ naar $\mathrm{q}$, en $\mathrm{s}_{\mathrm{qq}}$ de tweede afgeleide). De eerste twee eigenschappen impliceren respectievelijk dat groei van de omzet van onderneming i statusverhogend werkt, terwijl groei van de rivaal - uiteraard - een statusverlagend effect heeft. De derde ongelijkheid stelt dat het marginaal nut van statusverwerving afneemt met de omvang van onderneming i. Dus: het nut van omzetgroei neemt af naarmate de onderneming groter wordt. De laatste eigenschap impliceert dat het marginaal nut van statusverwerving afneemt met de omvang van de rivaal. Met andere woorden: hoe groter de marktstatus van een rivaal $\mathrm{j}$, hoe moeilijker het wordt voor onderneming i om via omzetgroei de eigen status te verhogen. Samengevat maximaliseert onderneming i de volgende nutsfunctie:

$u(\Pi, s(q, Q))$

Merk op dat deze nutsfunctie aansluit bij klassieke modellen in het domein van de "managerial theory of the firm", waarbij gesteld wordt dat ondernemingen niet enkel winst maximaliseren maar ook gedreven worden door andere motieven - zoals omvang (Baumol, 1953) en groei (Marris, 1964). Het wezenlijke verschil is dat via nutsfunctie (5) expliciet wordt uitgegaan van de veronderstelling dat het nut van omvang (en/of groei) afhangt van de relatieve positie die de onderneming in de markt bekleedt. Indien we veronderstellen dat de nutsfunctie additief separabel is, heeft de reactiefunctie de volgende richtingscoëfficient:

$d q / d Q=\left(u_{s s} s_{q} s_{Q}+u_{s} s_{q Q}\right) /\left[-\left(u_{\pi m}+u_{s s}\left(s_{q}\right)^{2}+u_{s} s_{q q}\right)\right]$

Het teken van de noemer is duidelijk positief. Het teken van de teller daarentegen is ambigu. De eerste term is positief. Een toename van $Q$ leidt tot een statusvermindering voor onderneming $\mathrm{i}$, hetgeen het nut van statusverwerving verhoogt. De tweede term is negatief aangezien de marginale marktstatus die kan verworven worden door omzetgroei, afneemt met Q. Deze tegenstrijdige effecten worden door Rauscher (1992) amplificatie- respectievelijk ontmoedigingseffect genoemd. Merk op dat deze effecten gelijkenis vertonen met wat W\&L (1990) imitatie (agressieve strategie) en accommodatie (vredelievende strategie) noemen. Het is duidelijk dat heuvelvormige reactiefuncties gegenereerd worden wanneer het amplificatie-effect overweegt bij een kleine omvang van de rivaal $(Q)$ en het ontmoedigingseffect domineert bij een grote $Q$.

Deze laatste veronderstellingen zijn zeker niet onrealistisch. De idee is dat een kleine onderneming snel geneigd zal zijn te accommoderen wanneer een grote onderneming haar 
productie (Q) uitbreidt. Een kleine onderneming heeft met name geen belang bij "head-on" concurrentie met een grote rivaal (Porter, 1980). Omgekeerd is het voor een grote onderneming relatief eenvoudig om elke poging van een kleine rivaal om marktaandeel te winnen af te straffen door ook haar productievolume te verhogen. In dit geval overweegt bijgevolg het amplificatieeffect. Wanneer beide rivalen ongeveer even groot zijn (dat wil zeggen: $q \approx Q$, hetgeen impliceert dat beide ondernemingen een vergelijkbaar marktaandeel hebben), overweegt noch het amplificatie- noch het ontmoedigingseffect. Dit is een interessant geval aangezien hierdoor een niet-stabiele en onvoorspelbare concurrentiestrijd ontstaat. Enerzijds heeft de onderneming de prikkel om agressief te reageren wanneer verwacht wordt dat de rivaal een expansiestrategie zal voeren. Anderzijds en tegelijkertijd kan de verwachting van escalerende concurrentie de onderneming afschrikken en accommodatie tot gevolg hebben. Ten gevolge van deze instabiliteit zouden wij dan ook de hypothese willen voorstellen dat chaotische patronen (escalatie van concurrentie afgewisseld met perioden van accommodatie) vooral zullen voorkomen in bedrijfstakken waar de rivalen ongeveer even groot zijn.

In deze paragraaf hopen we duidelijk te hebben gemaakt dat de inzichten die volgen uit de toepassingen van de chaostheorie in concurrentiemodellen, tot op heden beperkt zijn gebleven. De belangrijkste reden hiervoor is dat onderzoekers onvoldoende aandacht hebben besteed aan het leggen van theoretische fundamenten onder de drijvende kracht van chaos, met name voldoend niet-lineare - heuvelvormige - reactiefuncties. Wij menen dat de introductie van andere motieven dan winstmaximalisatie in de nutsfunctie van ondernemingen een opening biedt. Dan rest echter nog altijd de vraag: hoe valide is deze chaostheoretische beschrijving van concurrentie in "echte" markten?

\section{CHAOSTHEORIE EN DE WERKING VAN PRODUCTMARKTEN}

In deze paragraaf verlaten we de mathematische wereld van Cournot en pogen we te evalueren in welke mate de chaostheorie in het algemeen mogelijkheden biedt om de werking van productmarkten beter te begrijpen. Dit is geen eenvoudige opdracht omdat we hiervoor het wiskundige houvast moeten ruilen voor potentieel conceptueel drijfzand. Het mag immers niet worden vergeten dat de chaostheorie in essentie niet meer is dan een mathematische beschrijving van complexe systemen. De vertaalslag van niet-lineaire mathematische dynamica naar conceptuele toepassingen is een hachelijke onderneming. Bij voorbeeld: in wiskundige termen zijn begrippen zoals niet-lineariteit, evenwicht en chaos ondubbelzinnig gedefinieerd. Binnen de conceptuele benadering worden deze termen te pas en te onpas overgenomen zonder dat duidelijk wordt gemaakt waarover wordt gepraat. Om de conceptuele valkuil - zoals beschreven door Romme en van Witteloostuijn (1997) zoveel mogelijk te vermijden, pogen we zo dicht mogelijk aan te sluiten bij de inzichten die volgen uit de mathematische benadering. Meer bepaald beperken we onze evaluatie van de mogelijkheden van de chaostheorie tot de cruciale vraag naar de waarschijnlijkheid van het voorkomen van chaotische regimes in "echte" markten. Om deze vraag te kunnen beantwoorden willen wij te rade gaan bij de theorievorming rond het gedrag van ondernemingen in de organisatiepsychologische en -sociologische literatuur (organizational behavior).

De vraag is dus of chaotische trajecten van productvolumina regelmatig voorkomen in de 
praktijk. Wij menen dat chaos in het algemeen eerder uitzondering dan de regel is. De reden hiervoor is dat het gedrag van economische agenten (in dit artikel de productiebeslissingen van ondernemingen) gekenmerkt wordt door twee gerelateerde krachten die stabiliteit bevorderen: (1) het gedrag van ondernemingen is onderhevig aan zowel interne als externe restricties die (tot doel hebben) voorspelbaar gedrag (te) genereren; en (2) ondernemingen trachten doelbewust de omgeving te beheersen aangezien zij geen baat hebben bij chaos. Het navolgende is een illustratieve - maar onvolledige - poging om deze gedachtengang te verwoorden.

Wat de gedragsrestricties betreft, valt op dat vele organisatiewetenschappers precies de andere kant van de chaosmedaille bestuderen. Meer bepaald wordt in het domein van de organisatie-ecologie de dubbelvraag gesteld waarom de meeste ondernemingen zo inert zijn en wat de gevolgen van deze inertie zijn voor de overlevingskansen van ondernemingen (Schreuder en van Witteloostuijn, 1992; Boone en van Witteloostuijn, 1995). Volgens de organisatie-ecologie is de capaciteit van ondernemingen om zich aan te passen aan wijzigingen in de externe omgeving uitermate beperkt ten gevolge van zowel interne als externe inertie. Voorbeelden van interne inertie zijn: verzonken kosten en transactiespecifieke investeringen, structurele en bureaucratische inertie alsmede tradities binnen de onderneming. Toe- en uittredingsbarrières alsmede externe beperkingen met betrekking tot de beschikbaarheid van relevante informatie zijn voorbeelden van externe inertie (Hannan en Freeman, 1977 \& 1989). De mate waarin ondernemingen inert zijn, hangt af van verschillende factoren, zoals bij voorbeeld de leeftijd van ondernemingen. Naarmate de tijd verstrijkt, manoeuvreren ondernemingen zich als het ware vast: meer en meer kosten worden verzonken, routines krijgen allengs de bovenhand, gedragspatronen krijgen steeds duidelijkere structuren, et cetera. (Hannan en Freeman, 1989). Al deze factoren werken uiteraard voorspelbaarheid in de hand. Een uitdagende gedachte van de organisatieecologen is dat deze relatieve inertie niet alleen een conditie is voor, maar ook en vooral de uitkomst is van natuurlijke selectieprocessen. Hiermee wordt bedoeld dat bedrijven die weinig veranderen, de grootste kans op overleven hebben. Frequente koerswijzigingen schaden de overlevingskansen van individuele ondernemingen. Economische agenten binnen en buiten de onderneming - zoals de werknemers, de managers, de leveranciers, de afnemers, de investeerders en zelfs de concurrenten - stellen prijs op betrouwbaarheid en continuïteit. Bij voorbeeld Hambrick en D'Aveni (1988) laten zien dat faillissementen van grote ondernemingen vaak vooraf worden gegaan door een aantal jaren van hyperactiviteit, waarin de desbetreffende bedrijven de ene strategiewijziging na de andere hebben doorgevoerd. Zo is het ook onwaarschijnlijk dat een onderneming waarvan het productievolume op en neer gaat als een jojo, een lange levensduur tegemoet gaat. De essentie is dat een vlotte en efficiënte economische (en sociale) interactie tussen economische agenten binnen en buiten de onderneming slechts mogelijk is bij een zeker niveau van relatieve inertie, continuïteit en voorspelbaarheid. Ondernemingen in een productmarkt hebben bijgevolg geen baat bij chaos.

De behoefte aan stabiliteit biedt op zich geen garantie dat chaos en instabiliteit (kunnen) worden vermeden. Bij voorbeeld: om het even welke strategische actie van een onderneming kan de continuïteit van een andere onderneming in het gedrang brengen en (ongewenste) escalatie van concurrentie veroorzaken. Om die reden trachten ondernemingen hun omgeving te beheersen in de zin dat ze strategieën ontwikkelen waarmee zij pogen stabiliteit af te dwingen. 
Met andere woorden: ondernemingen hanteren chaosreducerende strategieën. Deze gedachtengang wordt uitstekend geformuleerd door Pfeffer en Salancik (1978: 114): "One of the problems faced by organizations interdependent with other organizations is that exchanges required for maintaining operations are uncertain and potentially unstable. Coping with organizational environments requires stabilizing them somehow .... When the conditions of the environment are mediated by social actors ... uncertainty derives not only from the vagaries of nature but from the actions taken by others. In such cases, the uncertainty resulting from the unpredictable actions of others is reduced by coordinating these actors". Voorbeelden van coördinatie- (lees chaosreducerende) strategieën zijn "lobbying", het verwerven van marktmacht in het algemeen, stilzwijgende en expliciete samenwerking, management- en bestuurder"interlocks", en fusies en acquisities. Indien ondernemingen chaosvermijding inderdaad belangrijk vinden, dan zou moeten kunnen worden vastgesteld dat de genoemde strategieën het meest voorkomen in omstandigheden met een grote kans op instabiliteit. Onderzoek suggereert dat dit inderdaad het geval is. We kunnen dit illustreren met twee voorbeelden.

In de vierde paragraaf stelden we dat de kans op chaos groter is in bedrijfstakken bestaande uit ondernemingen met (ongeveer) gelijke marktaandelen. Dit is consistent met de resultaten van empirisch onderzoek dat acquisities, fusies, "joint ventures" en "interlocks" van managers en bestuurders meer voorkomen in bedrijfstakken met een gemiddelde concentratiegraad dan in bedrijfstakken met een hoge concentratiegraad (Pfeffer, 1972; Pfeffer en Nowak, 1976; Pfeffer en Salancik, 1978). Een tweede voorbeeld heeft betrekking op de strategische acties van ondernemingen naar aanleiding van de Europese eenmaking. Deze eenmaking heeft aanleiding gegeven tot een golf van fusies, acquisities en allianties in de jaren tachtig (Sleuwaegen, 1991; Hagedoorn en Schakenraad, 1993). De literatuur is meestal ongenuanceerd met betrekking tot het verklaren van zowel de oorzaken als de gevolgen van deze golf. Wat de oorzaken betreft, wordt beweerd dat ondernemingen met deze strategische acties noodzakelijke rationalisaties en schaalvoordelen realiseren ten einde de concurrentiepositie te verstevigen (Sleuwaegen, 1991). Daarmee worden echter goede empirische en theoretische argumenten om deze simplistische voorstelling te nuanceren vergeten. Ten eerste is het duidelijk dat deze acquisities, fusies en allianties niet enkel gemotiveerd zijn door winst en/of efficiëntie. Zo blijkt uit onderzoek dat het aantal bedrijfstakken waarin daadwerkelijk schaalvoordelen kunnen geobserveerd worden, zeer beperkt is (Vanlommel en De Brabander, 1978). Porter (1987) vindt eveneens dat slechts een klein aantal ondernemingen erin slaagt synergieën ("economies of scope") te realiseren naar aanleiding van een acquisitie of fusie. Wij sluiten ons dan ook aan bij Pfeffer (1982: 206) die stelt dat "[s]tructural autonomy, or freedom from external constraint, and the ability to constrain or affect other firms motivate the various cooptive strategies used by firms. Power may have profit outcomes, but profit or efficiency is not the sole or perhaps even dominant motivating force". Samenvattend menen wij dat de concentratiegolf voor een groot deel een (anticiperende) reactie kan zijn geweest van ondernemingen die de potentiële chaos ten gevolge van de Europese eenmaking wensten te beheersen.

Wat de gevolgen van de eenmaking betreft, beweren de "Europese optimisten" dat deze herstructureringen tot lagere kosten en, gegeven de hoge concurrentiedruk, lagere prijzen leiden (Sleuwaegen, 1991). Ook deze bewering wensen we te nuanceren. Ten eerste worden 
oligopolistische interactie en bijgevolg (stilzwijgende) samenwerking eenvoudiger naarmate de concentratiegraad toeneemt. Ten tweede leiden deze herstructureringen tot een toename van het aantal (product- en geografische) markten waarop dezelfde ondernemingen elkaar ontmoeten. Aangezien een agressieve actie van een concurrent in één markt verregaande gevolgen kan hebben op alle andere markten, hebben "multicontact"ondernemingen baat bij het bewaren van de competitieve vrede (van Wegberg, van Witteloostuijn en Roscam Abbing, 1994). Met andere woorden: ook hier hebben we aanwijzingen dat deze herstructureringsgolf inderdaad de concurrentiële stabiliteit helpt te bewerkstelligen. Meer nog: deze strategische acties van ondernemingen blijken zelfs winstgevend te zijn op langere termijn, niet zozeer door een verhoging van de efficiëntie maar door toename van de marktmacht.

Merk op dat we geenszins beweren dat chaotische patronen in productmarkten niet zouden (kunnen) voorkomen. Ondernemingen zijn ingebed in een complex netwerk van interdependenties waardoor productmarkten potentieel chaotisch zijn (Thiétart en Forgues, 1995). We hebben enkel beargumenteerd dat ondernemingen geen baat hebben bij chaos, en precies daarom trachten deze interdependenties te beheersen door het verwerven van marktmacht. Hierdoor menen wij dat het voorkomen van chaos in eerste instantie beperkt zal zijn in de tijd. Met andere woorden: relatief korte perioden van chaos, veroorzaakt door om het even welke (wel of niet voorspelbare) exogene (bij voorbeeld oliecrisis) of endogene (bij voorbeeld agressieve strategische actie van een concurrent) gebeurtenis, worden gevolgd door perioden van een relatief stabiele evolutie naar een nieuw temporeel evenwicht. Dit impliceert dat de richting waarin bij voorbeeld een bedrijfstak evolueert, sterk bepaald wordt door de aard van de chaosinducerende gebeurtenis en bijgevolg een gevoelige afhankelijkheid van intiële condities vertoont. Het belang van de chaostheorie ligt ons inziens vooral in dit laatste inzicht, met name dat toevallige padafhankelijkheden de richting bepalen van de evolutie van bedrijfstakken. Het pleidooi van David (1988) dat de economische theorie een historische wetenschap moet worden ("Putting the past into the future of economics"), is dan ook van toepassing op de industrielle organisatie.

De ideeën uitgewerkt in dit artikel, ten slotte, suggereren dat niet alle productmarkten even gevoelig zijn voor het voorkomen van chaos. Om te beginnen kan eenvoudig worden aangetoond dat in Bertrand-concurrentiemodellen, waarin prijzen in plaats van hoeveelheden strategisch worden gemanipuleerd, enkel symmetrische reactiepatronen kunnen voorkomen (van Witteloostuijn, 1988). Hoewel eenvoudig te bewijzen, is deze bevinding niet direct intuïtief. De gedachtengang is de volgende. Indien enkel het prijsniveau als concurrentiewapen wordt gehanteerd, is het onmogelijk een niet-lineaire reactiefunctie te construeren. Immers: de enige zinvolle reactie op een prijsverlaging van een rivaal is om ook zelf de prijzen te verlagen. Dat wil zeggen: in de standaard Bertrand-context (zonder productheterogeniteit) is een verhoging van de eigen prijs in reactie op een prijsverlaging van een rivaal nooit winstgevend. Dit impliceert dat chaos minder waarschijnlijk is op markten waar de prijs het belangrijkste strategische wapen van concurrenten is - vergeleken met Cournot-markten waarop ondernemingen concurreren met hoeveelheden. Cournot-modellen beschrijven bedrijfstakken waarin de productietechnologie het niet toelaat productievolumina snel aan te passen aan wijzigingen in de vraag zonder aanzienlijke kosten. Bij voorbeeld in de automobielindustrie worden vooraf geplande hoeveelheden aan "dealers" verkocht. Deze "dealers" gebruiken desnoods allerhande kortingen om de uiteindelijke 
vraag op het aanbod af te stemmen. In bedrijfstakken waar flexibele productietechnieken een snelle aanpassing van hoeveelheden mogelijk maken, is de prijs een belangrijk strategisch wapen. Verzekeringsondernemingen bepalen bij voorbeeld normaal gesproken eerst hun tarieven om vervolgens hun diensten te verkopen aan zoveel mogelijk klanten. Indien onze theoretische voorspellingen correct zijn, zouden ceteris paribus meer chaotische patronen moeten kunnen worden geobserveerd in de productievolumina van automobielproducenten dan in de tarieven van verzekeringsondernemingen. Dit is uiteraard een empirische kwestie die nader onderzoek vergt.

Daarnaast vermoeden wij dat chaos relatief onwaarschijnlijk is wanneer de machtasymmetrie tussen concurrenten op een productmarkt groot is (bij voorbeeld grote verschillen in marktaandeel). Grote ondernemingen kunnen zowel de omgeving beheersen als voorspelbaar gedrag van minder machtige concurrenten afdwingen. De essentie is dat perioden van chaos vooral zullen optreden in markten waarop geen enkele partij de uitkomst van de interacties kan beheersen. Dit laatste is mogelijk de reden waarom financiële markten, die bovendien Cournotmarkten zijn, zoveel chaos vertonen. Deze proposities suggereren dat chaostheorie bij toepassing op de industriële organisatie aan verklaringskracht kan winnen door een systematische aanwending van de aloude contingentiegedachte. 


\section{NOTEN}

1 Onder productmarkten wordt het geheel van markten verstaan waarop zowel producten als diensten aangeboden worden.

2 In dergelijke Cournot-modellen is productie synoniem met verkoop: alle goederen die worden geproduceerd, worden ook via de markt aangeboden en verkocht, nadat op deze markt een marktruimende prijs - gegeven het geaggregeerde aanbod - is vastgesteld.

3 Merk op dat voor strategische substituten de richtingscoëfficient van de reactiefunctie negatief is (dit is het standaard geval in Cournot-duopoliemodellen). Als deze richtingscoëfficient positief is, hebben we te maken met strategische complementen.

4 W\&L (1990) onderzoeken drie gevallen: een dualist concurreert tegen een imitator (met een agressieve strategie), een dualist heeft een rivaal die accommodeert en beide rivalen zijn dualisten. In elk van deze gevallen wordt het bewijs voor het bestaan van chaotische regimes geleverd.

5 Zoals verderop zal blijken, kan marktstatus ook geïnterpreteerd worden als relatieve marktmacht. 


\section{REFERENTIES}

Baumol, W.J. (1953) Business Behaviour, Value and Growth, New York: McMillan.

Baumol, W.J. \& Benhabib J. (1989) Chaos: Significance, mechanism, and economic applications, Economic Perspectives, 3, 297-318.

Benhabib, J. \& Day, R.H. (1980) Erratic accumulations, Economic Letters, 6, 113-117.

Benhabib, J. \& Day, R.H. (1982) A characterization of erratic dynamics in the overlapping generations model, Journal of Economic Dynamics and Control, 4, 37-55.

Boone, C.A.J.J. \& Witteloostuijn, A. van (1995) Industrial organization and organizational ecology: the potentials for crossfertilization, Organization Studies, 16, 265-298.

Brock, W.A. (1986) Distinguishing random from deterministic systems: Abridged version, Journal of Economic Theory, 40, 168-195.

Bulow, J.I, Geanakoplos, J.D. \& Klemperer, P.D. (1985) Holding idle capacity to deter entry, Economic Journal, 95, 178-182.

Burgelman, R.A. (1983) Corporate entrepreneurship and strategic management: Insights from a process study, Management Science, 29, 1349-1364.

Cournot, A. (1987) Researches into the Matehematical Principles of the Theory of Wealth, New York: McMillan (eerste druk in het Frans in 1838).

Dana, R.A. \& Montrucchio, L. (1986) Dynamic complexity in duopoly games, Journal of Economic Theory, 40, 40-56.

David, P.A. (1988) Path dependence: Putting the past into the future of economics, Technical Report No. 533, The Economic Series, Institute for Mathematical Studies in the Social Sciences, California, Stanford University.

Freedman, D.H. (1992) Is management still a science?, Harvard Business Review, November-December, 26-38.

Goldstein, J.A. (1988) A far-from-equilibrium systems approach to resistance to change, Organizational Dynamics, 17, 1626.

Hagedoorn, J. \& Schakenraad, J. (1993) Strategic technology partnering and international corporate strategies, in K. Hughes (red.) European Competitiveness, Cambridge: Basil Blackwell.

Hambrick, D.C. \& D'Aveni, R.A. (1988) Large corporate failures as downward spirals, Administrative Science Quarterly, 33 , 1-23.

Hannan, M.T. \& Freeman, J. (1977) The population ecology of organizations, American Journal of Sociology, 82, 929-964.

Hannan, M.T. \& Freeman, J. (1989) Organizational Ecology, Cambridge, MA: Harvard University Press.

Kelsey, D. (1988) The economics of chaos or the chaos of economics, Oxford Economic Papers, 40, 1-31.

Li, T.Y. \& York, J.A. (1975) Period three implies chaos, American Mathematical Monthly, 985-992.

Marris, R. (1964) Theory of 'Managerial' Capitalism, London: McMillan.

May, R.M. (1976) Single mathematical dynamics with very complicated dynamics, Nature, 276, 458-467.

Nonaka, I. (1988) Creating organizational order out of chaos: Self-renewal in Japanese firms, California Management Review, 30, 57-73.

Pfeffer, J. (1972) Merger as a response to organizational interdependence, Administrative Science Quarterly, 17, 382-394.

Pfeffer, J. \& Nowak, P. (1976) Joint ventures and interorganizational interdependence, Administrative Science Quarterly, 21, 398-418.

Pfeffer, J. \& Salancik, G.R. (1978) The External Control of Organizations: A Resource Dependence Perspective, New York: Harper \& Row. 
Pfeffer, J. (1982) Organizations and Organization Theory, Cambridge, MA: Ballinger Publishing Company.

Porter, M.E. (1980) Competitive Strategy: Techniques for Analyzing Industries and Competitors, New York: Free Press.

Porter, M.E. (1987) From competitive advantage to corporate strategy, Harvard Business Review, mei-juni, 43-59.

Rand, D. (1978) Exotic phenomena in games and duopoly models, Journal of Mathematical Economics, 5, 173-184.

Rausher, M. (1992) Keeping up with the Joneses: Chaotic patterns in a status game, Economic Letters, 40, 287-290.

Romme, A.G.L. \& Witteloostuijn, A. van (1997) Autopoiesis, chaos, zelforganisatie en bedrijfskunde: Een chaotisch modeverschijnsel of ordelijke structuurwijziging? Bedrijfskunde: tijdschrift voor modern management, 68, in druk.

Schreuder, H. \& Witteloostuijn, A. van (1992) De ecologie van organisaties en de economie van bedrijven, M\&O: tijdschrift voor organisatiekunde en sociaal beleid, 69, 250-276.

Sleuwaegen, L. (1991) The restructuring of European manufacturing industries, in A.M. Rugman \& A. Verbeke (eds.) Research in Global Strategic Management, Volume 2: Global Competition and the European Community, Greenwich, CT: JAI Press, 81-102.

Spence, A.M. (1977) Entry, capacity, investment and oligopolistic pricing, Bell Journal of Economics, 8, 534-544.

Spence, A.M. (1979) Investment strategy and growth in a new market, Bell Journal of Economics, 10, 1-19.

Thiétart, R.A. \& Forgues, B. (1995) Chaos theory and organization, Organization Science, 6, 19-31.

Tirole, J. (1988) The Theory of Industrial Organization, Cambridge Mass.: MIT Press.

Vanlommel, E. \& De Brabander, B. (1978) Economies of scale, minimum optimal plant size and effectiveness of market structure in Belgian industry anno 1970, European Economic Review, 11, 363-373.

Vickers, J. (1985) Delegation and the theory of the firm, Economic Journal, 95, 138-147.

Ware, R. (1985) Inventory holding as a strategic weapon to deter entry, Economica, 52, 93-101.

Wegberg, M. van, Witteloostuijn, A. van \& Roscam Abbing, M. (1994) Multimarket and multiproject collusion: Why European integration may reduce intra-community competition, De Economist, 142, 253-285.

Wijnberg, N.M. \& Janszen F.H.A. (1993) Chaos, catastrofe, zelf-organisatie \& bedrijfskunde, Bedrijfskunde, 65, 71-79.

Witteloostuijn, A. van (1988) Chaos theory and industrial organization: A note on the application opportunities, $\underline{\text { Research }}$ Memorandum, Maastricht: Faculty of Economics and Business Administration, RM 88.017.

Witteloostuijn, A. van \& Lier A. van (1990) Chaotic patterns in Cournot competition, Metroeconometrica, 41, 161-185. 
Figuur 1: Een heuvelvormige reactiefunctie 
Tabel 1: Initiële waarden van simulatie-experimenten

\begin{tabular}{||c|c|c|c||}
\hline \hline $\begin{array}{c}\text { Simulatie- } \\
\text { experiment }\end{array}$ & $\begin{array}{c}\text { Initiële monopolie- } \\
\text { productie }\end{array}$ & $\begin{array}{c}\text { Initiële waarde } \\
\text { van } \alpha\end{array}$ & Figuur \\
\hline I & 0,310 & 3,35 & 2 \\
II & 0,300 & 3,35 & 3 \\
III & 0,310 & 3,34 & 4 \\
IV & 0,998 & 3,35 & 5 \\
\hline
\end{tabular}


Figuur 2: Chaotische patronen 
Figuur 3: Gevoelige afhankelijkheid van monopolieproductie 
Figuur 4: Gevoelige afhankelijkheid van parameterwaarde 
Figuur 5: Kwalitatieve breuken 